much more extensive than has been hitherto supposed. Specimens are described, taken from thirteen outcrops.

3. "On the Origin of the Permian Breccias of the Midlands, and a Comparison of them with the Upper Carboniferous Glacial Deposits of India and Australia." By R. D. Oldham, Esq., F.G.S.

The author first describes the Permian breccias of the Midland Counties of England, which he had the opportunity of examining at Eastertide of the present year. He describes the characters of the breccias, and concludes that they were formed subaërially as gravelfans by rivers charged with a maximum load of sediment, and therefore incapable of performing any appreciable amount of erosion. An examination of many of the fragments at Abberley and some at Church Hill reveals the presence of scratches, which occur in such a manner that the author believes they existed on the fragments before they were transported, and discusses the evidence for their production by ice or soil-cap movement, deciding in favour of the former.

A short description of the Upper Carboniferous deposits of India follows, and it is pointed out that they differ markedly from the deposits of Britain. Amongst other things the separation of different pebbles by considerable interspace of matrix, and the bending of stratification-planes round a pebble as though the pebble had dropped from above, are noted, and it is maintained that floating ice alone will account for these pebbles being dropped into the Indian deposits. Finally, it is remarked that the so-called Upper Carboniferous deposits of India and the Permian deposits of the Midlands of Britain may be practically contemporaneous, as maintained by the late Mr. H. F. Blanford, indicating a possible simultaneous existence of glaciers in England, India, and Australia.

\title{
COREFSPONDEIVOF.
}

\section{NORWEGIAN ROCKS IN THE ENGLISH BOULDER-CLAYS.}

Sir,-Anyone familiar with the Boulder-clays of our East Coastor, I may add, with the methods of working customary among field-geologists-must have read with astonishment Sir Henry Howorth's confident suggestion that the records of "so-called Norwegian boulders" are due to material brought by ships as ballast. In the first place, he clearly has no idea of the immense profusion of these boulders, hundreds of which may be observed in as many yards on some parts of the Holderness beach. This is in places where the Basement Clay is exposed in the cliffs and to the south of such places, i.e. in the direction of movement of the beach. If, however, Sir H. Howorth can find an adequate explanation of this in the statistics of ship-wrecks, he still has to meet the fact that these boulders are found not only on the beach but in the clay. Five years ago I examined and described specimens of the Laurvig augite-syenite collected by Mr. Lamplugh from the Basement Clay of Dimlington and Bridlington Quay. This was merely that my 
friend and myself might be perfectly satisfied of the identification of this rock-type. The fact that such rocks occur as boulders in the clay had long been a matter of common knowledge, and half an hour's work at the cliffs will always produce specimens of this angite-syenite and of the equally characteristic rhomb-porphyry, the two most striking rocks among the beach material. Surely it would $b_{e}$ " more in accordance with scientific laws of evidence" to ascertain the facts of the case, either personally or from the records, before propounding an artificial explanation of them.

If further evidence be needed, I may add that $I$ have recently sliced and examined typical specimens of the two unique Scandinavian rocks mentioned above, which were collected at Cambridge by Professor Hughes.

St. John's College, Cambridge, June 2 nd, 1894.

Alfred Harker.

\section{UNIFORMITY IN GEOLOGY AND THE ORIGIN OF THE DRIFT.}

Sir,-Sir Henry H. Howorth opens a rather strangely reasoned paper in your last month's issue with the statement that signs are. accumulating everywhere that geologists are now harking back to the views of the old catastrophists, and giving up the uniformitarian views so ably placed on record by Lyell and later workers. Where these signs are to be seen $I$ am at a loss to discover. Certainly not in the Nottingham Address of Mr. J. J. Harris Teall to the geological section of the British Association, nor yet in the text-books and original papers written during the last fow years. No doubt popular magazine writers will to some extent regard Sir Henry H. Howorth's writings as being one of the signs of the times, and will be ready to put his ideas before their readers as "recent advances." Every supporter of uniformitarian principles admits that floods and earthquakes have always occurred. Nor am I aware that any exact limit has been fixed to their magnitude. At least I never heard it argued that the eruption of Krakatoa, for example, was the greatest outburst that has ever occurred, or that there will never be a greater. It only asks us to seek to explain the facts by slow and well-known causes that may be seen in everyday action rather than by extreme or violent means. For instance, the great majority of geologists consider that the distribution of the drifts can be best accounted for on the assumption that large portions of the northern continents were covered by immense ice-fields. Judging from the present distribution of glaciers and ice-fields, etc., Sir Henry H. Howorth thinks this view extreme and not sufficiently uniformitarian, and pins his faith on floods and dancing mountain ranges. The time has gone by for a general discussion on this point. If a particular deposit can only be explained on the assumption that there was a deluge, we must believe that there was a deluge. It would be unscientific to settle upon the agent first and then point to all sorts of deposits as being produced by it.

But, to return to the paper, my intention was also to refer to 